\title{
Barred from Change: The Incarceration of Children and Young People in Northern Ireland
}

Moore, L., \& Convery, U. (2008). Barred from Change: The Incarceration of Children and Young People in Northern Ireland. Current Issues in Criminal Justice, 20(1), 79-94.

http://www.heinonline.org/HOL/Page?handle=hein.journals/cicj20\&id=1\&size=2\&collection=journals\&index=journ als/cicj

Link to publication record in Ulster University Research Portal

\section{Published in:}

Current Issues in Criminal Justice

Publication Status:

Published (in print/issue): 01/07/2008

\section{Document Version}

Publisher's PDF, also known as Version of record

\section{General rights}

Copyright for the publications made accessible via Ulster University's Research Portal is retained by the author(s) and / or other copyright owners and it is a condition of accessing these publications that users recognise and abide by the legal requirements associated with these rights.

\section{Take down policy}

The Research Portal is Ulster University's institutional repository that provides access to Ulster's research outputs. Every effort has been made to ensure that content in the Research Portal does not infringe any person's rights, or applicable UK laws. If you discover content in the Research Portal that you believe breaches copyright or violates any law, please contact pure-support@ulster.ac.uk. 


\section{HEINONLINE}

Citation: 20 Current Issues Crim. Just. 79 2008-2009

Content downloaded/printed from HeinOnline (http://heinonline.org)

Sat Jan 23 11:39:04 2010

-- Your use of this HeinOnline PDF indicates your acceptance of HeinOnline's Terms and Conditions of the license agreement available at http://heinonline.org/HOL/License

-- The search text of this PDF is generated from uncorrected OCR text.

-- To obtain permission to use this article beyond the scope of your HeinOnline license, please use:

https://www.copyright.com/ccc/basicSearch.do? \&operation $=$ go\&search Type $=0$ \&lastSearch $=$ simple\&all=on\&titleOrStdNo=1034-5329 


\title{
Barred from Change:
}

\section{The Incarceration of Children and Young People in Northern Ireland}

\author{
Linda Moore and Una Convery ${ }^{*}$
}

\begin{abstract}
Based on primary research conducted for the Northern Ireland Human Rights Commission (Convery \& Moore 2006) ${ }^{1}$ this article explores the care of children in the Juvenile Justice Centre for Northern Ireland [JJC or the Centre] in the context of their rights. The research followed from a previous Commission investigation (Kilkelly et al 2002) which identified serious breaches of rights. Still in Our Care was based primarily on qualitative research with children, staff and managers in the JJC where children aged 10 to 17 were remanded or sentenced to custody. This article concludes that despite legislative change and various reviews of the youth justice system, the state in Northern Ireland persists in consigning some of the most vulnerable and challenging children to incarceration within a 'total institution' (Goffman 1961) from the industrial and reformatory schools of the 19th century, through to the juvenile justice centre of the 21 st century. Finally, the article considers the need for a transformation in the state's response to children in conflict with the law and the potential of the Bill of Rights process for achieving this.
\end{abstract}

\section{The Impact of Conflict on Children and Young People}

Northern Ireland is in the process of emerging from a long and bloody conflict which led to trauma, suffering and hardship for many children and even to death and injury. Over 3,600 people died and many thousands were injured over the past 30 years, over a third of deaths were children and young people (Smyth 2004). Assessing the impact of the 'particular circumstances of Northern Ireland' on children, Horgan (2005) identifies death and injury, bereavement, witnessing violence including bombings and shootings, police and army raids on homes, paramilitary punishment attacks and imprisonment of a parent. Communities suffering the worst violence of the conflict were those with highest levels of poverty (see Haydon \& Scraton this issue). McWhirter (2002:83) states, "it is poorer people who have

* Dr Linda Moore and Dr Una Convery are Lecturers in Criminology, the School of Policy Studies at the University of Ulster.

1 This article is based on primary research conducted by the authors for the Northern Ireland Human Rights Commission. The authors are indebted to the Commission for the opportunity to conduct the research. Any opinions expressed in this article are the authors' own and should not be attributed to the Commission. The authors are also grateful to stafi, managers and especially the children at the JJC for their help with the research. 
borne the brunt of the Northern Ireland "Troubles" either in their areas or their lives'. The effects of inter-generational trauma have been exacerbated by a long-standing deficit in adolescent mental health services (Kilkelly et al 2004). Lamenting the 'negative impact of the conflict situation in Northern Ireland on children', the United Nations Committee on the Rights of the Child (UNCRC 2002:para 53) expressed particular concerns regarding emergency legislation and plastic bullets (paras $27 \& 28$ ).

The Good Friday/Belfast Agreement 1998 acknowledged divisions about policing and criminal justice and established an independent commission on policing (the Patten Commission) and a wide ranging review of the criminal justice system (Criminal Justice Review). There was a conspicuous failure to refer to youth justice in the Review's consultation document (CJR 1998) and it was only as a consequence of the response of the Criminal Justice (Children) Lobby Group (1999) that these issues were included within the Review Group's remit. The final report of the Criminal Justice Review (CJR 2000) noted continued concerns about the operation and management of the juvenile justice process and the treatment of 'juvenile offenders'. Recommendations included the expansion of restorative justice programmes, fuller incorporation of 17 year olds within the remit of youth courts and a greater emphasis on international human rights standards. The Review failed to recommend an increase in the minimum age of criminal responsibility which remained at 10 years, and on two successive occasions this had been the subject of criticism by the UN Committee on the Rights of the Child (UNCRC 1995, 2002).

The paramilitary ceasefires and transformation of 'security' arrangements, including a greatly reduced use of emergency powers in local communities, have had a positive impact on the lives of children and young people throughout Northern Ireland. Transition from 'long term and deep rooted conflict', however, is a 'long and complex process' and 'sporadic and opportunist conflict' continues (Kilkelly et al 2004:243). Kilkelly et al also identify continuing problems including negative relations between the police and young people, displacement and homelessness resulting from paramilitary feuding and sectarian attacks, street violence and lack of safety for young people in local areas. Further, there is currently debate within civil society involving the main political parties concerning a Bill of Rights for the North, which children's rights advocates hope will contribute to a new respect for the rights of the child including a human rights based framework for dealing with children in conflict with the law.

\section{Incarcerating Children in the North of Ireland: Custodial Provision}

During the 20th century much of the North's youth justice legislation was based on the English model, although as Powell (1982:565) notes 'provision for the young offender in Northern Ireland tended to evolve more slowly than in other parts of the UK'. The 1908 Children Act confirmed the age of criminal responsibility at seven years and established the juvenile court for children under 16. The Children and Young Persons Act Northern lreland) 1950 raised the age of responsibility to eight and brought 16 year olds within the jurisdiction of the juvenile court. It required the courts to have regard to the 'welfare' of the child. The Act replaced reformatory and industrial schools with the generic term 'training schools' in which children could be detained for welfare and justice reasons for indeterminate periods.

The 1950 legislation allowed children as young as 14 to be transferred from training schools to prison custody. In 1968 the age of criminal responsibility was raised to 10 . Eleven years later a report by the Children and Young Persons Review Group (1979), the 
Black Report, recommended significant changes in the system including the separation of criminal justice and welfare proceedings for children. This was not implemented until the 1995 Children (Northern Ireland) Order marked the separation of child care and juvenile justice legislation.

The 1996 Criminal Justice (Northern Ireland) Order replicated the statutory framework, established in England and Wales, for the regulation of sentencing decisions concerning adults and children. The Government failed to take account of criticisms of developments in England and Wales (Ashworth \& Gibson 1994; Harding \& Koffman 1995) and the Order was introduced in the absence of research on sentencing decisions in Northern Ireland. The central principle of the 1996 Order is the concept of proportionality in sentencing, with children and adults receiving their 'just deserts'. It determined that custody should only be used when other punishments would depreciate the seriousness of the offence. According to O'Mahony and Deazley (2000:60) the intention was to restrict custodial sentences to 'genuinely serious offenders and not ... petty, yet troublesome, young offenders'. However, the Northern Ireland Office (1996:para 1.9) stated that it would be used for 'serious and persistent offenders' (emphasis added).

Rather than radically reform the response to children in the criminal justice system, the 1998 Criminal Justice (Children) (Northern Ireland) Order re-acted earlier legislation and introduced some changes echoing the Black Report recommendations. The juvenile court, renamed the youth court, was retained but its jurisdiction was not extended to 17-year-olds and provisions for the trial of children as young as 10 in an adult court continued. The Order failed to replace the lesser requirement of the 'child's welfare' with the Convention on the Rights of the Child (Article 3) principle of the 'child's best interests'. Under the 1998 Order Northern Ireland's four training schools (Lisnevin, St Joseph's, St Patrick's and Rathgael) were renamed juvenile justice centres (JJCs). A new determinate sentence, the juvenile justice centre order (JJCO) was introduced, normally to be for six months and for no longer than two years. The JJCO provided for the detention of children under 17 to secure custody followed by a period of supervision of equal length in the community. The 1998 Order raised the age limit for the remand and committal of children in Prison Service custody from 14 to 15 and introduced alternative criteria for imprisonment including a child's risk of selfharm. This was indicative of the Government's failure to apply Article 37(c) of the CRC or to implement Chief Inspector of Prison's (HMCIP 1997) recommendation that children should not be detained in Prison Service custody. It also failed to acknowledge criticism of Prison Service inadequacies concerning suicide and self-harm (HMCIP 1995, 1997; Liebling 1995, 1998; Negy et al 1997) and apply Article 24 to establish children's right to the highest attainable standard of health care.

Evidence suggests that these legislative developments followed developments in England and Wales and were introduced without sufficient regard to the broader context in which children in the North live. Also it appears that the 1998 Order was hurried through in an attempt to exclude youth justice from the Criminal Justice Review thus avoiding the introduction of more radical changes to the juvenile justice system. Recommendations made by the Review (CJR 2000) were included in the 2002 and 2004 Justice (Northern Ireland) Acts but, reflecting previous trends, the provisions were added to existing legislation.

The 2002 Act brought 17-year-olds within the jurisdiction of the youth court, providing for the detention of some in a JJC and introducing new community-based disposals. However, the 2002 and 2004 Acts failed to address concerns (Kilkelly et al 2002) about the over-use of remand. Further, there was no increase in the age of criminal responsibility and 
no expressed commitment to the principle of the child's best interests. Provisions for the detention of 15- and 16-year-olds in the prison system were retained for some circumstances and the emphasis on secure custody in the juvenile justice system prevailed. This response clearly defied evidence (Lockhart et al 1986; Curran et al 1995) that the more secure the disposal the greater the possibility of re-offending on release. It also defied extensive criticism of similar practices in England and Wales, namely the introduction of secure training centres (Penal Affairs Consortium 1993, 1994; Howard League 1995; UNCRC 1995; Goldson 1997) and the detention of children in the prison system (HMCIP 1997; Howard League 1997, 1998). Although the 2004 Act explicitly recognised the need for human rights standards to be applied the relevant provision remains dependent on the future devolution of justice powers to Northern Ireland.

Following the implementation of the 1998 Order the JJC estate was rationalised. Lisnevin, designed on the model of a Category $\mathrm{C}$ prison, formerly a Borstal, with a central Panopticon and a seven metre perimeter fence topped with razor wire, became the dominant custodial disposal for boys. Only one unit in Rathgael remained open for the detention of girls and some 'vulnerable' boys. St Patrick's, a more open centre, also provided for boys until its closure in November 2001. A place for one girl was provided in St Joseph's until its closure in March 2000.

Lisnevin had been heavily criticised for the neglect of the building and for being a depressing, bleak and inadequate environment for children (Horgan \& Sinclair 1997; SSI 1998). There were persistent calls for its closure (CJCLG 1999, 2000; NIHRC 2000). In November 2000, the Northern Ireland Office (NIO) announced its decision to close Lisnevin and St Patrick's and to replace the JJC estate with one centre. In October 2003, Rathgael, which had been redeveloped, became the single JJC and in January 2007, was replaced by Woodlands JJC on the same site. The new $£ 16.8$ million centre, with a capacity of 48 boys and girls, was based on the model of St Mary's Kenmure, near Glasgow. This was contrary to recommendations (Kilkelly et al 2002) that small, family-sized units, based in local communities would be more in keeping with international human rights standards.

A further development in the provision of custody for children included the transfer of women and girls from Maghaberry Prison in June 2004 to Ash House, a unit within Hydebank Wood which was a YOC for young men and boys. Scraton and Moore (2004:179) found the primary reason for the transfer was 'cost efficiency and not the advancement of a humane regime appropriate to the assessed and acknowledged needs of women and girls'. Relocation failed to tackle extreme issues regarding the imprisonment of women and girls highlighted by Scraton and Moore (2004) and the HMCIP (2002). This included the circumstances in which two young women died in Prison Service custody (see Scraton \& Moore 2004, 2007).

The use of Ash House for girls and women, including extremely damaged young women at risk of self-harm and suicide, was considered inappropriate due to profound concerns about the facilities, the regime, and staff support and training (HMCIP/CICJ 2005a; Scraton \& Moore 2007). Further, holding boys in Hydebank Wood alongside young adults contravenes international standards on the treatment of children in custody. Boys' experiences, including limited access to education, over-use of special cells and strip clothing in cases of self-harm and insufficient staff training in child protection, also have been documented (HMCIP/CICJ 2005b).

The 2008 Criminal Justice (Northern Ireland) Order purportedly intends to end prison custody for girls. Where the Secretary of State decides there is no suitable accommodation in the YOC for 17-year-olds the requirement will be detention in the JJC. As the Prisons 
and Criminal Justice Inspectorates (HMCIP/CICJ 2005a) and the Human Rights Commission (Scraton \& Moore 2007) have declared Hydebank Wood unsuitable, it is presumed that the Order prevents its use for girls. Yet the lack of specific prohibition of prison custody for girls leaves a legal loophole. Should the Secretary of State in future deem it 'suitable' then girls could still be imprisoned on a 'YOC' landing within the women's prison.

\section{Still in Our Care: Research Findings}

The research demonstrates that, contrary to international standards, custodial sentences and remands are not used as a last resort or for the shortest possible period. Official figures for 2005 show the number of children (41) sentenced to the JJC had increased by 14 per cent on the previous year. They also highlight the unacceptably high level of admissions under remand, with the majority being remanded by the court under the 1998 Order ( 55 per cent) and the remainder held under the Police and Criminal Evidence Order (Northern Ireland) (1989) (PACE) (31 per cent). Interviews revealed that a number of children, particularly those on remand, had been returned to the Centre up to four times and one 14-year-old boy had been in the Centre on 16 separate occasions. Staff also raised concerns about the detention of children for relatively minor offences alongside children detained for serious offences:

You could have a boy in because he's broke windows and you could have a boy in because he's attempted murder, and that's a fault ... You've also got boys in here with maybe 100 car crimes and they're mixing with the window breaker, maybe selling drugs and that.

Contrary to international and domestic law, inappropriate use of remand was demonstrated by pre-trial detention not restricted to exceptional circumstances. PACE also facilitated the use of the JJC for holding purposes. Only 14 per cent of children remanded under the 1998 Order were subsequently sentenced to custody ( 81 per cent received bail, 4 per cent were released and 1 per cent had charges dropped) and 40 per cent of PACE admissions were discharged. The over-use of remand had continued despite the introduction of bail support through the provision of foster and residential placements and criteria for admissions under PACE.

At the time of the research, staff regarded the seven placements available to be insufficient to meet demand. Bail support was lacking: 'If the courts can give bail after two weeks or one month they should be able to give it after two days, instead young people are in for months ... some are remanded as long as ones are sentenced'. They were concerned particularly about children remanded from 'looked after care' (LAC) due to the lack of specialist services and alternatives to custodial remand: 'There's a lot of good work in the community, but there's still too many coming in to custody that shouldn't. It's a lot about support accommodation'. Children also recognised the lack of alternatives: 'The judge just had me remanded because they can't get me a place'. The need for more community-based provision was reinforced by staff: 'I had concerns around a vulnerable child, a 'care child' in the unit with [a young person] who is highly dangerous with serious psychological problems and emotional issues ... We need more fostering placements'.

A further explanation given by staff and children for the over-use of custody was the failure of solicitors and/or social workers to attend court hearings:

The court was happy to grant bail but because there was no social worker there he was remanded. (staff) 
I was remanded because there was no-one there to represent me ... My solicitor's ... never there ... The day I was put in here, he spoke to me for about five minutes and told me that whenever I went up to the court that he would see me. I went up ... and there was someone there representing me that I didn't even know. (child)

Staff called for reforms to prevent the over-use of custody for children from LAC backgrounds as over half the children detained in the Centre ( 52 per cent) at the time of the research were 'care cases'. It was considered that conditions for children bailed from custody 'are so stringent you know they're going to fail ... PACE children come from children's homes. If they breach bail because they're not back at 9pm, they [children's home staff] call the police'. Restorative measures were suggested as a possible alternative for these cases. Staff gave further examples of the inappropriate use of the JJC for children from care backgrounds. This highlighted the lack of stability experienced by children and their mental health needs:

We have had a few shocking cases ... We had a boy who'd been in over 210 homes in 10 years ... That was horrendous ... and then you wonder why he offends ... When they go back out they want to come back in. That was true of this boy ... This is the longest period of time of stability he's had in his life.

He was in and out of the [children's home] consistently ... He's in for nuisance offences ... He has serious learning difficulties and there's a concern that this may lead to serious harm.

I think the number of young people getting in from the care side is frightening. Some are disturbed, some are clearly suffering from mental illnesses, psychological problems ... You could be in a house where you're taken out of it for your own safety and put in a children's home and the first thing you know, you're locked up here.

The JJC is located in Bangor, approximately 10 miles from Belfast. ${ }^{2}$ At the time of research its capacity was up to 40 boys and girls, aged 10 to 17 years. During fieldwork there were only two girls in the Centre, one of whom was considered by staff too vulnerable and distressed to be interviewed. The Centre comprised a series of house units set in an area surrounded by trees, each house with an enclosed exercise space at the rear. Despite the 'domestic' style of the units, the wire fence and level of security at the entrance demonstrated it was a secure centre.

Children were brought to the JJC either by the police or a private security firm. It was common for children to be handcuffed during escort. One child showed red marks on his wrists which he alleged had been caused by handcuffs. On admission children were given a 'pat down' search and although this did not involve the removal of clothing, the enforced intimacy could prove upsetting:

I hate other men touching my body. I hate people touching my body. I hate anyone touching my body. I don't like people touching my body at all ... they touch you there [points to top of legs] search you and you feel like hitting them.

Following reception, a member of staff assessed and settled children and they were permitted to telephone their families:

... [in] that first couple of hours show them round, they do start feeling at ease. See the place isn't a prison. (staff)

Entering custody, particularly for the first time, was an anxious time for children, all kids are scared ... They all need reassurance, they're still kids. (staff)

2 The JJC has since been rebuill on the same site and renamed as 'Woodlands'. 
The welcoming attitude of staff and other children and the small scale of the units helped allay children's fears but the experience of being locked alone in their bedrooms caused difficulties in sleeping during the early days in custody:

It was a bit scary because all I done was sat and stared at the ceiling until about two or three in the morning.

... thinking about things when you've no TV or anything. I think everyone should have TV... 'cause when you're in your bedroom, in your room, you can think about things. You can think about strange things, so you can ... like hanging yourself or something. Thought about it a few times.

The Criminal Justice Inspection Northern Ireland (CJINI 2005:68) described the interior of house units as 'domestic and homely'. While the former was a fair description, the latter was over-stated. Conditions in the Intensive Support Unit (since closed) were physically austere. Dining tables and beds were bolted to the floor and it contained a bare cell used as a 'time out' room. The Centre had a school, Rowan College, and separate sports facilities including a swimming pool. Daily life was productive with an emphasis on education, interaction with staff and a range of activities. Children preferred being busy, to avoid dwelling on problems. Unit meetings took place each morning between children and staff.

Behaviour was measured according to a 'progressive regime' and rewards given accordingly, including later bed-times or having a television, compact disc player or Play Station in bedrooms. Children held for longer periods experienced a plateau effect on reaching the highest 'platinum' grade with no further advancement possible within the regime. Staff and children ate together in house units and staff commented on the poor diets that some children experienced in the community. One boy commented that he and his companion had not been eating prior to entering custody as they were 'on the run'. He enjoyed the Centre's 'healthy eating' programme. Children's health, including dental care was addressed. Many had not received routine dental services in the community and the dentist described how a 'reflection of neglect' was evident in tooth decay.

The extent of the crisis in child and adolescent mental health services in Northern Ireland is well-documented (Kilkelly et al 2004) and many children in the Centre had troubled lives and experienced mental ill-health and trauma: 'young people are coming in now with more mental health issues. Psychologists [outside] won't touch them with a barge pole' (staff). The Centre employed a full time psychologist and was in the process of recruiting additional support. Yet the extent to which the psychologist could carry through individual casework was limited by the high level of remands and rapid turnover of children. It was considered inappropriate to begin individual casework on deep-seated problems when a child was likely to be in custody for a brief time or when their future was uncertain. Care staff were concerned that more resources were needed to support and respond effectively to children with mental health problems:

A boy in here was on the borderline of psychosis. Everyone else here thought he was just a bad git ... mental illness in young people presents differently. You wouldn't know unless you know the signs to look for.

I think staff should have more training re dealing with young people with mental health problems: basic counselling course, body language, how to listen.

Children were relieved the Centre was not as 'prison like' as they had anticipated:

They give you everything you want. It's like a holiday camp. It's the best place to be if you want to do your time. 
I thought it was going to be something where you were locked in a cell and you weren't out of it ... You come in here - you're out, you're doing football, you're swimming, you've TVs and Play Stations. I didn't think it would be like that.

However, some aspects, such as night-time lock up, were clear reminders of their detention:

You have to ring the buzzer [to go to the toilet at night]. It's annoying sometimes if you're in your room and you're trying to sleep and then someone rings the buzzer, and you hear the buzzer and then you can't sleep.

l've seen them [night staff] but I don't really talk to them ... Only contact l'd have is asking them to turn the light off.

Anxiety about being in custody, and their personal problems, were exacerbated by an absolute ban on smoking:

You wo'sld wake up angry some mornings. Angry at yourself for being here. A cigarette would calm you down.

Every day you'te here, it just gets worse because every time you watch 'TV or anything, you see somebody sitting with a cigarette and it just makes me think, and then I just get worse and worse.

There was a positive emphasis on education and many children had been absent from school for months or even years, through suspension, expulsion or truancy. A broad range of subjects were available and children were taught in small groups. Teachers were required to address a wide variety of educational needs, as a consequence of the diverse age group and levels of ability and the rapid and unpredictable movement of children. They agreed that a high level of short-term remands made it difficult to plan effectively for each individual. Interviews with children indicated that their involvement in the school had enhanced their confidence and they appeared actively interested in classroom activities. A boy, expelled from school in the community, stated:

I'll be doing cartooning, art and design, maths, geography. There's so many classes I haven't done yet. I've done business studies and I've done swimming. I ended up swimming in here and I haven't swum for about three years. I was sitting around and I says 'I'Il try it'. I went and got in and all, and was swimming up and down the very best. I thought, 'I can't believe I've just done that'.

Sadly, the boy predicted that following release he would be unable to continue the subjects he was enjoying. For one girl the school was 'amazing' and had improved her confidence significantly. She did not relish returning to school in the community because 'when teachers shout at me, I shout back at them'.

Children confirmed there was no restriction on the frequency of visits by their families but practicalities and the relative inaccessibility of the Centre made visits difficult and infrequent for some families. Buses to the Centre were provided by the Northern Ireland Association for the Care and Resettlement of Offenders (NIACRO) from Belfast at weekends. Visits took place in the house dining area, supervised by staff who considered their presence was important to ensure safety. They believed supervision did not breach children's privacy:

If a young person and his mother's at one table, I would be sitting in the corner, or another member of staff making cups of tea and ... you know we're there to support them as well. Any questions that parents have, hopefully we'll get the answers ... Half the times [the young person will] turn around and say, 'Come and sit beside us'.

Children, however, expressed mixed views about the lack of privacy during visits: 
Some staff come over and sit right beside you ... I feel like telling them to go away. If I done that l'd get an adverse report.

If I'm speaking to my mum or my wee brother, I would like a bit of privacy. But that is the rules and regulation.

Younger siblings often were bored and there were suggestions that activity-based visits would have encouraged more interaction. Some children found visits upsetting: 'Look out the window and see them leaving. It annoys you'. Others refused visits as they became too distressed:

I don't really like visits. Just do without them. Seen my ma and dad once, but they leave and you don't. I don't like when you're sitting here and they go. You'd like to be going back out.

Daily telephone calls were permitted but restricted to 10 minutes under staff supervision:

You're only on the phone, you're only getting into the conversation by 10 minutes and then they come in, and you're half way through the conversation and then they come in, and they tell you to turn it off, put the phone down.

Life in the Centre was highly monitored and regulated. Requests by children to spend time in their bedrooms were monitored with written observations at a minimum of five minute intervals depending on the young person's mood. Children had little privacy and could only move about the campus when escorted by care and security staff:

... they treat them like category ' $A$ ' prisoners. You have to have a member of ops [operations staff] to escort you wherever you go and I think that's shocking'. (staff)

Managers explained the high level of security was a consequence of children previously absconding from more open regimes. A child conceded that 'if there was no fence I wouldn't be sitting here. I'd be out and away'. Other explanations included the close-knit nature of Northern Ireland's communities, in which children often were aware of each other's alleged crimes and involved in various sides of disputes. For some children who had experienced chaos and insecurity in their lives, the strong element of regulation gave a sense of safety:

This is more secure, so it is [than care home]. There's more security and more safety and all.

A lot of the young people welcome that [controlled] environment. They don't have boundaries in their lives outside. This is giving them a structure. A lot of them don't eat at proper times or don't have proper medical [attention]. Here, everything is taken care for them. (staff)

For other children high levels of control and surveillance were stifling:

I wanted outside and staff have to watch you no matter where you turn; you can't open doors and you can't do anything, so you can't. Now I'm used to it anyway ... [at the start] it was stressing, stressing so it was.

You're just stuck in here all the time. You have no energy, don't do nothing.

Most staff considered that following positive risk assessments trusted children should be given more freedom of movement:

There's about five or six young people in here at the moment that you could take anywhere with you. They wouldn't even think about [absconding].

The first investigation by the Human Rights Commission (Kilkelly et al 2002) expressed serious concern about high levels of physical restraint. Subsequent staff training in 'therapeutic crisis intervention' (TCI) was instrumental in significantly reducing its use but restraint remained routine. During the 18 months preceding fieldwork, the highest recorded number of restraints in one month was 30 , the lowest four. Restraint involved staff 'holding' 
a child without bringing her/him to the ground. Officially this was not defined as a 'pain compliance technique' but children confirmed that pain was caused. All children interviewed had either seen another child being restrained or had been restrained themselves:

\begin{abstract}
See when I get out of hand like, it's their job to control me ... I've seen about ten [staff] on a kid about that size [indicates small child]. It hurts them ... if they hurt them, it makes them more mad. It really makes them out of control.
\end{abstract}

It's not fair ... shouldn't take six people to hold a wee boy down. They got a shield and made his nose bleed. Bent his fingers back. It's supposed to calm you down, but it makes you more angry.

They're not allowed to put handcufts on for a fact; they put handcuffs on me and then started ... they nearly broke my wrists. I had cuts and everything right there, they were pulling that hard ... When I first saw someone else getting restrained, I felt like helping the other wee lad instead of helping staff. This wee lad, a wee small thing, not even five foot and these men about six foot, and he was just getting jumped over ... it looked like they nearly killed him. He couldn't breathe or nothing. He's going 'I can't breathe, I can't breathe' and staff didn't listen to him.

Incidents of violence and threats of violence by children directed at staff were documented in house records: 'young person threatened to "break staff's fucking jaw"' (a member of staff was 'kneed in the face' in this incident); 'tried to head butt staff member'; 'threatening to stab staff'. Sometimes, crisis intervention techniques were used successfully: 'young person lunged towards staff to strike, verbally aggressive but de-escalated very quickly using TCI techniques'. However, the researchers also witnessed threats to restrain and isolate a child for refusing to go to bed at the required time. He simply wanted to have a drink of juice.

There is no Youth Justice Agency strategy for girls in custody and JJC policies did not specifically address gender needs. Girls always are a small minority in the Centre and at the time of fieldwork, they were accommodated in a mixed gender house with a female house manager. Staff were aware of girls' particular vulnerability:

It's difficult, stressful for girls ... girls need special programme time. Some young girls have very special needs.

Boys also commented on girls' distress:

Some of the wee girls do your head in ... All the wee girls in here cry ... they just cry. Everything they do. One of the wee girls [is] doing my head in for nothing, just sitting and watching TV and won't stop crying.

The one girl interviewed 'didn't mind' that, at one stage, she had been the only girl in the Centre although she raised the issue of privacy. While coping well she enjoyed other girls' company and would have preferred a girls-only unit. Homophobia was also a recurring theme, and during fieldwork there were several incidents where children made anti-gay remarks in the presence of staff which were either ignored or mildly challenged. For example staff referred to their personal friendships with gay people. During anger management programmes when boys were asked what made them angry they often mentioned homosexuality.

There were no statistics available on religious affiliations of children admitted to the Centre, making equality analysis impossible. Nor was there monitoring of the operation of the regime by gender or religion - for example, the use of physical restraint. Staff and children confirmed the Inspectorate's view (CJINI 2005) that religious and political differences were rarely an issue between children from different communities, perhaps 
because so many had been subject to intimidation and/ or 'physical punishment' by paramilitary groups:

Young people understand that each other have come from similar backgrounds and have a shared history. At the end of the day, young people themselves have chosen not to annoy each other with sectarian callings. (staff)

Human rights standards require rehabilitation and resettlement of young people to be a primary goal of custody. Staff and children were pessimistic regarding the potential for the programmes offered or custodial experience in general to 'reform' or 'rehabilitate'. Assessment, planning and rehabilitative work were difficult when children were in the Centre only for a few days. Support work directly related to alleged offending behaviour could not be carried out for fear of interfering with the right to fair trial, and presumption of innocence. Staff and children held a shared scepticism about the effectiveness of dedicated crime reduction programmes:

In my opinion they [programmes] haven't been very effective, but we're hoping to improve ... the boys are coming back. They're only out a week or a fortnight and they're back having stolen another car. So how do you judge? (staff)

Kids are coming in off the street, smacked off their heads. They really are and there's nothing for them drug-wise in here. There's the drug awareness programme and that's it and when you think of the amount of money they spend on them [the programmes] that's absolutely shocking. (staff)

We know it already [drug awareness] ... It's a waste of time. (child)

No evaluations or follow-up studies were available to test effectiveness of programmes. Ultimately, the pressures on children returning to the community were significant:

We're sending them back to 10 mates [friends] who all steal cars every night and take drugs every night. That peer pressure is massive. (staff)

Many staff considered that the high level of care children received in the Centre, including education and healthcare, contributed to addressing their offending behaviour more than crime reduction programmes:

We need to address offending behaviour, but we need to look at the bigger picture at the welfare of children, their right to be safe and cared for.

A young interviewee provided insight into his life demonstrating the complexity of problems facing children in custody, including the impact of bereavement, family breakdown, experience of paramilitaries and being placed in the looked-after care system. He described his grief and anger following his father's death, which he considered the root of his problems:

Fell out with most of my family. They didn't talk to me for a while. I felt like nobody wanted me. None of my friends would hardly talk to me because I was in the children's home ... I've just been like that from [when] my dad died. My dad died when I was 11 ... I just get this big thing of anger inside me and it's coming out bit by bit. A wee bit's coming out at a time, but if I get that worked up it's all going to come out at once.

She [the psychologist] asked me about my whole life and I don't really like talking about it because there's that much things has happened in my life, between watching my friends die. You know l've actually seen two of my friends die. And then watching one when he was getting knee-capped, getting shot, punishment beat and whatever. I don't like talking about it because I go nuts. But ['ve seen myself in anger [while being video taped by friend]. I ran 
round my room, I lifted my wardrobe and I clean threw it at the walls, smashed it, headbutted my walls ... By the time I finished, my room was a bomb-site.

\section{Conclusion}

As Scraton and Haydon (2002:326) argue:

... children's offending and antisocial behaviour, like their other life experiences and personal opportunities, are located within powerful structural determining contexts. Through unemployment, poverty and differential opportunities class impacts significantly on communities, families and children.

In Northern Ireland conflict can be added to this list (Kilkelly et al 2004; Horgan 2005). Children in custody are drawn from the most conflict-ridden, poorest communities and it is to those communities they return on release. Reintegration is difficult when many have never been integrated into their local communities in the first instance, subject to differential policing from the state, punishment attacks administered by non-state paramilitary organisations and curfews and informal restrictions imposed by nonparamilitary vigilante groups (Kilkelly et al 2004). Community-based restorative justice initiatives offer an alternative but struggle to gain adequate funding and resources to meet the challenge of dealing with young people with deep-seated problems who then come into conflict with the law.

Reviewing the history of institutions for children in Northern Ireland over the past century and noting the cross-over of children from care into custody, Evans (2007:212) writes: 'in spite of valid and sincere attempts to improve the quality of care which children and young people receive when being looked after by the state, there is still a reliance on institutional-type custody for a minority'. The current research concurs that custody is overused particularly for short-term remands, persistent but non-violent offences, and for children from the looked-after care system. To comply with international children's rights standards (CRC Articles $37 \& 40$ ) greater provision of alternatives to custody is required. The Committee on the Rights of the Child in its General Comment on Juvenile Justice (UNCRC 2007) reminds member states that custody and criminalisation must not be used for children for offences which for an adult would not result in the same treatment. Yet, for children in the care system in Northern Ireland this is often the case.

The educational experience for children in the JJC enhanced the confidence of many children but this contrasted to the abject failure to meet their needs in mainstream schools in the community. Similarly children's mental health needs were too often addressed for the first time in a custodial setting. As Stephenson (2007:40) notes, although several studies identify a 'positive impact' on 'young people's attitudes towards education and training' through custodial experience, 'it is unknown how much of this positive shift is a reflection of the very restricted positive experiences in custody and thereby likely to be short-lived'.

Separation of children from families and friends inherently limits the effectiveness of attempts at rehabilitation as children generally return to a challenging environment not conducive to desistance from offending. The use of physical restraint, handcuffing, high levels of security and surveillance, and lack of privacy each represented possible breaches of rights to life and to loss of dignity and privacy (ECHR Articles $2,3 \& 14$ ). The continued use of Prison Service custody for children and low age of criminal responsibility remain breaches of children's rights. The UN Committee on the Rights of the Child comments that because of children's vulnerability and needs, the traditional objectives of the criminal justice system (repression and retribution) must give way to principles of restoration and rehabilitation (UNCRC 2007:para 4b). While secure facilities may be necessary for a small 
minority of children, the use of custody as a punishment has no place in the rights-based youth justice system envisaged by the Convention.

Goldson and Muncie (2006:216) have mapped the 'broad contours' of a principled youth justice system including a raised age of criminal responsibility and a reductionist approach to incarceration. Such a youth justice system is long overdue in Northern Ireland and too many opportunities to transform the system have been missed. The failure of successive governments to incorporate international human rights standards in legislative provision, to make policy decisions informed by accurate, up-to-date information, and to take account of the social and political context within which children live must be addressed. A key commitment of the 1998 Good Friday/Belfast Agreement was full consultation on a future Bill of Rights for Northern Ireland. This process is ongoing and representatives of children's organisations are determined that the opportunity will not be missed to develop a rights-based approach to criminal justice including a commitment to end the criminalisation of children under the age of 16 and to restrict the incarceration of children and young people to an absolute minimum (Bill of Rights Forum 2008).

\section{References}

Ashworth A \& Gibson B 1994 'The Criminal Justice Act 1993: Altering the Sentencing Framework' Criminal Law Review 41 pp 101-109

Bill of Rights Forum 2008 Final Report of the Working Group on Children and Young People Bill of Rights Forum Belfast (available at: www.billofrightsforum.org)

Children and Young Persons Review Group 1979 Report of the Children and Young Persons Review Group HMSO Belfast

Criminal Justice (Children) Lobby Group (CJCLG) 1999 Submission to the Criminal Justice Review Group February Belfast

Criminal Justice (Children) Lobby Group (CJCLG) 2000 Response to Review of the Juvenile Justice Secure Estate Review June Belfast

Criminal Justice Inspection Northern Ireland 2005 Inspection of the Juvenile Justice Centre Northern Ireland October 2004 Criminal Justice Inspection Northern Ireland Belfast

Criminal Justice Review Group (CJR) 1998 Review of the Criminal Justice System in Northern Ireland: A Consultation Paper The Stationery Office Belfast

Criminal Justice Review Group (CJR) 2000 Review of the Criminal Justice System in Northern Ireland, 30 March The Stationery Office London

Curran D Kilpatrick R Young V \& Wilson D 1995 'Longitudinal Aspects of Reconviction: Secure and Open Intervention with Juvenile Offenders in Northern Ireland' The Howard Journal vol 34 no 2 pp 97-12

Evans H 2007 'Institutions' in M Robb (ed) Youth in context: frameworks, settings and encounters Open University and Sage London

Goffman E 1961 Asylums: Essays on the Social Situation of Mental Patients and Other Inmates Anchor Books New York 
Goldson B 1997 'Children, Crime, Policy and Practice: Neither Welfare nor Justice' Children \& Society vol 11 pp 77-88

Goldson B \& Muncie J (eds) 2006 Youth Crime and Justice Sage London

Harding C \& Koffman L 1995 Sentencing and the Penal System: Text and Materials (2nd ed) Sweet \& Maxwell London

HM Chief Inspector of Prisons (HMCIP) 1995 Report on HM Young Offenders' Centre Hydebank Wood (Northern Ireland) by HM Chief Inspector of Prisons Home Office London

HM Chief Inspector of Prisons (HMCIP) 1997 HM Prison Maghaberry (Northern Ireland) Report of an Unannounced Full Inspection Home Office London

HM Chief Inspector of Prisons and the Chief Inspector of Criminal Justice in Northern Ireland (HMCIP/CICJ) 2005a Report on an Unannounced Inspection of the Imprisonment of Women i: Northern Ireland Ash House Hydebank Wood Prison 28-30 November 2004 CJINI Belfast

HM Chief Inspector of Prisons and the Chief Inspector of Criminal Justice in Northern Ireland (HMCIP/CICJ) 2005b Report on an Unannounced Inspection of Hydebank Wood Prison and Young Offender Centre 14-17 March 2005 CJINI Belfast

HM Inspectorate of Prisons for England and Wales (HMIP) 1997 Young Prisoners: A Thematic Review by HM Chief Inspector of Prisons for England and Wales Home Office London

Horgan G \& Sinclair R 1997 Planning for Children in Care in Northern Ireland National Children's Bureau London

Horgan G 2005 Particular Circumstances of Children and Young People in Northern Ireland Children's Law Centre Belfast (available on website: www.childrenslawcentre.org)

Howard League 1995 Banged Up, Beaten Up, Cutting Up: Report of the Howard League Commission of Inquiry into Violence in Penal Institutions for Teenagers under 18 Howard League for Penal Reform London

Howard League 1997 The Howard League Troubleshooter Project: Lessons For Policy and Practice on 15 Year Olds In Prison Howard League for Penal Reform London

Howard League 1998 Prisons Within Prisons HLM: The Howard League Magazine vol 16 no 4 November $\mathrm{p} 3$

Kilkelly U Moore L \& Convery U 2002 In Our Care: Promoting the Rights of Children in Custody NIHRC Belfast

Kilkelly U Kilpatrick R Lundy L Moore L Scraton P Davey C Dwyer C \& McAlister S 2004 Children's Rights in Northern Ireland Northern Ireland Commissioner for Children and Young People Belfast

Liebling A 1995 'Vulnerability and Prison Suicide' The British Journal of Criminology vol 35 no 2 Spring pp 173-187 
Liebling A (ed) 1998 Deaths of Offenders: The Hidden Side of Justice Waterside Press Winchester

Lockhart W McAuley M \& Brennan S 1986 A Follow Up Study of Young Offenders Released from Secure Custody Extern Belfast

McWhirter L 2002 Health and Social Care in Northern Ireland: A Statistical Profile Information and Analysis Unit Department of Health and Social Services and Public Safety Belfast

Negy C Woods DJ \& Carlson R 1997 'The Relationship between Female Inmates' Coping and Adjustment in a Minimum-Security Prison' Criminal Justice and Behaviour vol 24 no 2 June pp 224-233

Northern Ireland Human Rights Commission (NIHRC) 2000 Northern Ireland Human Rights Commission: Response to the Future of the Juvenile Justice Centre Estate Review NIHRC Belfast

Northern Ireland Human Rights Commission (NIHRC) 2001 Making a Bill of Rights for Northern Ireland: $A$ Consultation by the Northern Ireland Human Rights Commission NIHRC Belfast

Northern Ireland Office (NIO) 1996 Scoping Study for Review of Juvenile Justice Provision NIO Criminal Justice Policy Division Belfast

O'Mahony D \& Deazley R 2000 Juvenile Crime and Justice: Review of the Criminal Justice System in Northern Ireland HMSO London

Penal Affairs Consortium 1993 A Step in the Wrong Direction: The Right and the Wrong Way of Tackling Juvenile Crime Penal Affairs Consortium London

Penal Affairs Consortium 1994 The Case Against the Secure Training Centre Penal Affairs Consortium London

Powell F 1982 'Justice and the Young Offender in Northern Ireland' British Journal of Social Work 12 pp 565-586

Scraton P \& Haydon D 2002 'Challenging the criminalisation of children and young people: Securing a rights-based agenda' in J Muncie G Hughes \& E McLaughlin (eds) Youth Justice: Critical Readings Sage London pp 311-328

Scraton P \& Moore L 2004 Report on the Transfer of Women from the Mourne House Unit, Maghaberry Prison to Hydebank Young Offenders Unit NIHRC Belfast

Scraton P \& Moore L 2007 The Prison Within: The Imprisonment of Women at Hydebank Wood 2004-06 NIHRC Belfast

Social Services Inspectorate (SSI) 1998 Overview Report of Inspection of Rathgael Centre 1997 DHSS Belfast

Smyth M 2004 The Concept of Childhood and the Experiences of Children in Violently Divided Societies Institute for Conflict Research Belfast 
Stephenson M 2007 Young People and Offending: education, youth justice and social inclusion Willan Cullompton.

UN Committee on the Rights of the Child (UNCRC) 1995 Consideration of Reports Submitted by States Parties Under Article 44 of the Convention: Concluding Observations of the Committee on the Rights of the Child: United Kingdom of Great Britain and Northern Ireland 27/1/1995 UN Doc. CRC/C/15/Add.34

UN Committee on the Rights of the Child (UNCRC) 2002 Consideration of Reports Submitted by States Parties Under Article 44 of the Convention: Concluding Observations of the Committee on the Rights of the Child: United Kingdom of Great Britain and Northern Ireland 9/10/2002 UN Doc. CRC/C/15/Add. 188

UN Committee on the Rights of the Child (UNCRC) 2007 General Comment No 10 (2007) Children's Rights in Juvenile Justice $\mathrm{CRC} / \mathrm{C} / \mathrm{GC} / 10$ 